\title{
Crisis adjustment strategies in France: The contribution of establishment-level data
}

\author{
Delphine Brochard and Corinne Perraudin *
}

\begin{abstract}
This paper explores the employment and wage adjustments and business reorganisation implemented by French establishments between 2008 and 2010, using data from the Dares REPONSE survey. Drawing up a typology of adjustment practices based on a statistical classification, it reveals a diversity of practices illustrating the complementarity of these adjustments. Then the paper analyses the characteristics of the different classes of establishments and the links between practices, the flexibility levers available to the establishments and their economic and financial dependency relationships, taking into account the diversity of economic and social contexts. While recourse to temporary contracts and subcontracting does not seem to be significant, the use of flexible pay components (individual pay rises and performance bonuses) and worker versatility affect the adjustments made by establishments. Likewise, being majority foreign-owned, being a subsidiary of a (listed or unlisted) group, or being part of a subcontracting chain emerge from the analysis as significant factors affecting these adjustments.
\end{abstract}

JEL Classification: D22, J53, J31, M54, G34.

Keywords: economic crisis, business practices, employment adjustment, wage adjustment, flexibility, corporate governance.

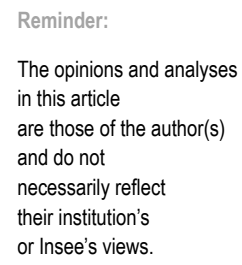

*CES (UMR 8174), University Paris 1 (delphine.brochard@univ-paris1.fr, corinne.perraudin@univ-paris1.fr).

We would like to thank Jérôme Gautié, Julie Valentin and three anonymous rapporteurs for their helpful comments. We bear sole responsibility for any errors. This paper is a follow-up to a research contract carried out within the framework of an agreement between Dares and the CES (Perez et al., 2015). 
$\mathbf{T}$ he employment impact of the shockwave that hit France in 2008 is commonly studied through an approach focused on the labour market, in which employment and wage adjustments are regarded as being substitutable, and institutional constraints are put forward as an explanation for the country's trajectory. These (often comparative) studies present France's trajectory as typically exemplifying employment adjustment strategy (mainly affecting those on fixed-term and, above all, temping contracts) or external flexibility, as opposed to internal flexibility involving variations in hours worked (as in Germany and Austria) and/or hourly wages (Askenazy et al., 2013; Cochard et al., 2010; Gautié, 2011; Horny et al., 2010; Marchand \& Minni, 2010; OECD, 2010). These adjustment characteristics are attributed to wage and employment regulations (Askenazy et al., 2013; Bentolila et al., 2012; Boeri \& Jimeno, 2016; Fabiani et al., 2015) and to the industrial relations system (Boulin \& Cette, 2013; Delpech et al., 2016; Dustman et al., 2014), which are supposed to give companies more or less flexibility and to affect the relative cost of alternative strategies.

The descriptive analysis of the effects of the crisis at firm level provides another perspective on adjustment mechanisms and their determinants. By examining the diversity of adjustment practices in the light of the specific context of each firm, it identifies a broader variety of practices and explanatory factors. The Dares REPONSE survey (a French survey of labour relations and collective bargaining) provides an opportunity to perform such an analysis. The latest REPONSE survey for the period 2008-2010 enables us to explore the employment and wage adjustment practices implemented by establishments with 10 or more employees (in the non-farm business sector), and to link these practices with a rich set of variables related to the internal organisation and the environment of firms. Initial analyses conducted respectively by Deroyon and Romans (2014) and Amossé et al. (2016) clarified the link between adjustment practices and labour relations within establishments, enabling the impact of the latter to be qualified. Indeed, these studies show that, while employment and wage adjustments have frequently gone hand in hand with collective bargaining, the latter seems to have facilitated rather than hindered the adjustments.

The aim here is to complete these findings by studying the influence of two other contextual factors on crisis adjustment practices: The organisational flexibility tools put in place by the establishment, and the economic and financial dependency relationships in which it is embedded. As shown by Atkinson and Meager (1986)'s seminal study, firms have developed a range of flexible labour management practices that go beyond the usual dichotomy between internal and external flexibility. As the development of these practices vary according to the industry, the size of the establishment and the skill level of the workforce (Bunel, 2008), these practices offer a range of adjustment opportunities to establishments grappling with the economic crisis, and are therefore likely to promote heterogeneity in adjustment mechanisms (Kümmerling \& Lehndorff, 2014). Another possible source of heterogeneity lies in the economic and financial dependency relationships in which establishments are engaged (Grimshaw \& Rubery, 2005). Whether they stem from the firm's governance structure -via the composition of its shareholder base, its listing on the stock exchange or its subsidiary status- or from its inclusion in a subcontracting chain, these relationships undermine the employer's autonomy and influence labour management decisions (Perraudin et al., 2008b).

To assess the impact of these various factors, we consider a broad range of adjustments, including actions on employment, wages and business reorganisation, as well as the possible combination of these adjustments within establishments. Using a typology of adjustment practices based on a statistical classification of establishments having seen a stagnation or decline in their business activity from 2008-2010, this paper presents a diversity of practices revealing the complementarity of the different adjustments made. It then describes the links between these practices, the flexibility levers available to establishments, and their economic and financial dependency relationships, while taking into account the diversity of economic and social contexts. It shows that, while recourse to temporary contracts and subcontracting does not seem to be a discriminant factor, the use of flexible pay components (individual pay rises and performance bonuses) and worker versatility emerge from the analysis as significant factors. Likewise, being majority foreign-owned, being a subsidiary of a (listed or unlisted) group, or being part of a subcontracting chain affects the adjustments made by establishments. 


\section{A variety of adjustment practices}

According to the REPONSE survey, only a small proportion of establishments report being affected by the first phase of the economic crisis: In fact, less than one quarter of establishments declare a decline or a strong decline in business from 2008-2010, and slightly more than a third declare no change. To assess the impact of the recession on the behaviour of establishments without restricting the sample size too much and thereby reducing its representativeness, we focus our study exclusively on these establishments (Box). The preliminary analysis shows that adjustments, no matter what the practices considered, are more frequent in establishments that have not reported an increase in business than in the overall survey sample. The most widespread adjustment practices are workforce reductions ( $27 \%$ of establishments), business reorganisation $(28 \%)$ and wage moderation $(29 \%)$. Only $17 \%$ of the establishments froze or reduced wages, and recourse to the French legal framework for short-time working is even more infrequent (7\%). These types of adjustments are made mostly by establishments facing a serious

\section{Box - Sample and data}

The Dares REPONSE survey (a French survey of labour relations and collective bargaining) allows us to study the various aspects of the employment relationship at establishment level. It provides information on how employee representative bodies work, human resource management practices, and work organisation, in connection with economic strategies and performance results. The 2010-2011 survey covered establishments with 11 employees or more, operating in the non-farm business sector in mainland France, excluding Corsica and individual family employers. Data were collected from 4,023 establishments between January and July 2011. The sample studied in this paper is restricted to establishments which reported no growth in their business volumes over the period in question, and information on adjustment practices of interest, i.e. 2,372 establishments. As a result of this restriction, establishments in the manufacturing and construction sectors, and small establishments, are slightly over-represented in the study sample (cf. Online Complement $\mathrm{C} 1$, table C1-1). The "management representative" section of the survey provides information on the key changes between 2008 and 2010, in terms of workforce (all types of contract included), pay, and business reorganisation.

The change in workforce is considered from a global perspective, with no distinction possible between fixedterm contracts and open-ended contracts. The question is as follows: "What trend has been observed in your establishment's workforce over the last three years (2008, 2009, 2010), including all employees: An increase, no change, or a decrease?" With regard to pay, the questionnaire includes a question relating specifically to the economic crisis: "In the last three years (2008, 2009, 2010), in response to the economic crisis, has your establishment adopted any of the following policies towards any or all categories of employees? Wage moderation; a pay freeze; pay cuts; no, none of these". Due to the small number of establishments reporting pay cuts (barely more than $1 \%$ ), this adjustment practice was grouped together with pay freezes. This question does not enable us to distinguish changes in different (fixed or flexible) pay components. However, it appears from its wording that the question excludes incentive bonuses and profit sharing, which vary not on a discretionary basis but automatically depending on the firm's performance and profits, respectively. Lastly, the questionnaire provides information on the incidence of business reorganisations, through the following question: "Over the last three years (2008, 2009, 2010), has your establishment implemented any of the following organisational changes? Three of the options proposed relate to defensive reorganisations: "Job redundancies"; "Refocus on specific businesses (abandonment of diversification)"; "Repatriation of subcontracted work". The selection of at least one of these options is considered here as meaning that the business has been reorganised.

To determine the extent of recourse to the legal shorttime working scheme, these data were matched with the administrative database SINAPSE (which is managed by the DGEFP - General Delegation for Employment and Vocational Training). It is therefore possible to know how many hours were actually unworked and paid under the "standard" or "long-term" short-time working scheme, for reasons other than accidents or exceptional bad weather (see Beauvoir \& Calavrezo, 2012). On this basis, a binary indicator of recourse to shorttime working over the period 2008-2010 was developed for each establishment.

The indicators used in the REPONSE survey do not show whether employment adjustments affected all employees equally across the board. Two further sources have been used to analyse these adjustments in greater detail, and to determine whether they affected all categories of employees, while maintaining the overall cohesion of the data used to develop the classification. On the one hand, the "employee" section of the REPONSE survey provides information on the incidence of collective redundancy plans through the following question: "In the last three years, have there been any collective redundancies in the establishment where you work?" If at least one employee from a given establishment replied "yes" (between 5 and 10 employees were surveyed per establishment), that indicates that the establishment carried out a collective redundancy plan between 2008 and 2010. On the other hand, establishment-level data from the 2008-2010 DADS (Insee) enable us to identify changes to the structure of jobs over the period, in terms of qualifications and (open-ended and fixed-term) contracts. 
decline in business (cf. Online Complement $\mathrm{C} 1$, Table C1-1).

The breakdown per sector and per establishment size also reveals a wide diversity of behaviours. The particularly gloomy situation in the manufacturing sector comes out very clearly, regardless of the adjustment considered. With regard to size, while the largest establishments have more frequently resorted to business reorganisations, short-time working, workforce reductions and wage moderation, the smallest establishments have been more likely to freeze or reduce wages (cf. Online Complement C1, Table C1-2).

The study of statistical associations between adjustment practices shows that the establishments often make a combination of adjustments (Table 1). If, overall, just over a quarter of the establishments have reduced their workforce, the conditional frequencies show that these establishments account for almost half of those that have reorganised their business, frozen or cut wages, or taken recourse to short-time working. Likewise, business reorganisations are carried out by around two out of five establishments that have frozen or cut wages, or have taken recourse to short-time working. They are two times less frequent among establishments that have not placed any restrictions on wages. Therefore -far from being an alternative to workforce reductions- wage freezes and cuts, business reorganisations, and short-time working often seem to be complementary practices, which prompts a more in-depth investigation of their combined used by establishments.

\section{Five classes of establishments and three crisis adjustment practices}

An ascending hierarchical classification (AHC), based on a multiple correspondence analysis $(\mathrm{MCA})^{1}$, was performed to identify typical combinations of adjustment practices. As a result, five classes of establishments were identified, according to their adjustment practices (Table 2). Two of these classes stand out for not taking recourse to short-time working, not cutting wages and workforce, and carrying out very few business reorganisations. They include two thirds of the establishments and slightly over half of the employees in the sample. The largest class is characterised by "workforce stability" ( $50 \%$ of establishments and $39 \%$ of employees), while the other, smaller, group is distinguished

\footnotetext{
1. The MCA was carried out on unweighted data, the aim being to analyse the links revealed by the raw data without replicating observations through the use of weighted variables. The AHC is based on variables corresponding to the establishments' projections on the first two factorial axes of the MCA, which means that the establishments are classified based on the adjustment variables shown in table 2. The first two axes were selected, firstly, because they contain a larger share of information than the average axis (i.e.17\%) and, secondly, to ensure that the less frequent modalities of the active variables did not influence the definition of the typology classes too much. Nevertheless, several variants were produced, and lead to comparable results.
}

Table 1

Conditional frequency of adjustments in establishments reporting no change or a decline in activity between 2008 and 2010

\begin{tabular}{|c|c|c|c|c|c|c|c|c|c|}
\hline & & \multicolumn{3}{|c|}{ Changes in pay } & \multicolumn{3}{|c|}{ Changes in workforce } & \multirow{2}{*}{$\begin{array}{l}\text { Business } \\
\text { reorganisation }\end{array}$} & \multirow{2}{*}{$\begin{array}{l}\text { Recourse to } \\
\text { short-time } \\
\text { working }\end{array}$} \\
\hline & & $\begin{array}{c}\text { No } \\
\text { restrictions }\end{array}$ & Moderation & $\begin{array}{l}\text { Freeze } \\
\text { or } \\
\text { reduction }\end{array}$ & Increase & No change & Decrease & & \\
\hline \multirow{3}{*}{$\begin{array}{l}\text { Changes } \\
\text { in pay }\end{array}$} & $\begin{array}{l}\text { No } \\
\text { restrictions }\end{array}$ & 100 & 0 & 0 & 22 & 58 & 20 & 22 & 4 \\
\hline & Moderation & 0 & 100 & 0 & 18 & 52 & 30 & 34 & 7 \\
\hline & $\begin{array}{l}\text { Freeze or } \\
\text { reduction }\end{array}$ & 0 & 0 & 100 & 13 & 40 & 47 & 39 & 19 \\
\hline \multicolumn{2}{|c|}{ Business reorganisation } & 42 & 35 & 23 & 17 & 37 & 46 & 100 & 11 \\
\hline \multicolumn{2}{|c|}{$\begin{array}{l}\text { Recourse to short-time } \\
\text { working }\end{array}$} & 28 & 27 & 45 & 9 & 41 & 50 & 45 & 100 \\
\hline \multicolumn{2}{|l|}{ Total } & 54 & 29 & 17 & 19 & 54 & 27 & 28 & 7 \\
\hline
\end{tabular}

Reading note: $27 \%$ of the establishments that reported no change or a decline in activity between 2008 and 2010 saw a decrease in their total workforce from 2008 to 2010; These establishments make up $47 \%$ of those that either froze or cut wages over the period.

Coverage: Establishments with 11 employees or more in the non-farm business sector, reporting no change or a decline in activity from 2008 to 2010 (weighted figures).

Sources: Dares REPONSE survey 2010-2011, "management representative" section, and Sinapse. 
by a "workforce increase" ( $16 \%$ of establishments and $18 \%$ of employees).

Conversely, the three other classes present typical combinations of adjustment practices. The first combination consists of "all adjustment practices": wage freezes or cuts (for $75 \%$ of the establishments), workforce reduction $(80 \%)$, recourse to short-time working $(64 \%)$ and business reorganisation (77\%), thus illustrating the possible complementarity of the different adjustment practices. However, this class contains $8 \%$ of the establishments studied (13\% of employees). Further analysis reveals the nature of the workforce reductions reported by the management representatives. According to the information in the "employee" section of the survey, over half of these establishments conducted a collective redundancy plan over the period and, according to $D A D S$ data (annual declarations of social data), neither permanent nor high-skilled employees were spared (see Online Complement C1, Tables C1-3 and C1-4).

The second combination, involving $15 \%$ of the establishments (22\% of employees), consists of workforce adjustments (for $75 \%$ of the establishments), wage moderation ( $70 \%$ of the establishments) and business reorganisations ( $76 \%$ of the establishments). Wage freezes and cuts are rare, as is recourse to short-time working. The joint occurrence of business reorganisations and workforce reductions suggests the use of "restructurings combined with wage moderation", without recourse to short-time working. According to the data on "employees", almost one third of these establishments have conducted a collective redundancy plan. Again, according to the $D A D S$, neither permanent nor high-skilled employees were spared.

A third and final combination, representing $11 \%$ of the establishments ( $8 \%$ of employees), is characterised above all by wage freezes or cuts (for $84 \%$ of the establishments), without, in most cases, any changes to the scope of the business. Recourse to short-time working is more frequent than average in this combination $(18 \% v s .7 \%)$, but is much less common than in the first class (64\%). Likewise, workforce reductions $(33 \%)$ are far less widespread than in the previous two combinations. The establishments in this class have mostly introduced "primarily wage-oriented adjustment combinations". According to the information in the "employee" section, almost one third of the establishments have conducted collective redundancy plans and, according to the $D A D S$, the job cuts affected the least qualified segment of the workforce most.

Table 2

Frequency of adjustments per class of establishment

\begin{tabular}{|c|c|c|c|c|c|c|}
\hline & $\begin{array}{c}\text { All adjustment } \\
\text { practices }\end{array}$ & $\begin{array}{c}\text { Restructuring } \\
\text { with } \\
\text { wage moderation }\end{array}$ & $\begin{array}{c}\text { Primarily } \\
\text { wage-oriented } \\
\text { adjustments }\end{array}$ & $\begin{array}{l}\text { Workforce } \\
\text { stability }\end{array}$ & $\begin{array}{c}\text { Increase } \\
\text { in workforce }\end{array}$ & All \\
\hline \multicolumn{7}{|l|}{ Changes in pay } \\
\hline Freeze or reduction & 75 & 4 & 84 & 3 & 0 & 17 \\
\hline Moderation & 18 & 70 & 4 & 23 & 31 & 29 \\
\hline No restrictions & 7 & 26 & 12 & 74 & 69 & 54 \\
\hline \multicolumn{7}{|l|}{ Changes in workforce } \\
\hline Increase & 1 & 7 & 2 & 3 & 100 & 19 \\
\hline No change & 19 & 19 & 65 & 85 & 0 & 54 \\
\hline Decrease & 80 & 74 & 33 & 12 & 0 & 27 \\
\hline Short-time working & 64 & 2 & 18 & 0 & 0 & 7 \\
\hline Business reorganisation & 77 & 76 & 15 & 10 & 24 & 28 \\
\hline$\%$ of establishments & 8 & 15 & 11 & 50 & 16 & 100 \\
\hline$\%$ of employees & 13 & 22 & 8 & 39 & 18 & 100 \\
\hline
\end{tabular}

Leading note: The class of establishments typically combining "all adjustment practices" contains $8 \%$ of establishments reporting no change or a decline in activity from 2008 to 2010 , i.e. $13 \%$ of employees. $80 \%$ of these establishments reduced their workforce, compared with $27 \%$ of the total sample.

Coverage: Establishments with 11 employees or more in the non-farm business sector, reporting no change or a decline in activity from 2008 to 2010 (weighted figures)

Sources: Dares REPONSE survey 2010-2011, "management representative" section, and Sinapse. 


\section{Complementary rather than substitutable adjustments}

Taken together, these three combinations of adjustments serve to qualify the observation made at macroeconomic level, namely that there is a preference for workforce reductions (external flexibility) rather than adjustments to wages and hours worked (internal flexibility). While the "restructuring with wage moderation" class is similar to this first model, it exists alongside a second class combining all of the adjustment practices, and a third class that mainly implements wage adjustments with or without short-time working. One third of the establishments in this class combine wage adjustments with workforce reductions.

These findings are in line with those of Deroyon and Romans (2014), who, based on the same survey, show that wage and employment adjustments are not mutually exclusive, and that wage freezes and reductions, and recourse to short-time working, are - all things being equal - positively associated with the probability of collective redundancy. They are also consistent with the conclusions of Calavrezo and Zilloniz (2016), showing that most of the firms that took recourse to short-time working between late 2007 and late 2010 nevertheless saw their workforce shrink over the period. This possible complementarity between wage bill reduction levers is also revealed by Teague and Roche (2014), using a similar methodology in a very different macro-institutional context. Classifying Irish establishments according to the adjustment mechanisms used, they distinguish two classes of equal size. One includes establishments that focus on cutting wages, working hours and jobs (general retrenchment programs), while the other includes establishments that opt to freeze wages and, to a lesser extent, reduce overtime. This complementarity is also revealed by the study conducted in Germany and the Netherlands by Tidjens et al. (2014), showing that, while downward adjustments on the intensive margin (hours per capita) and/or the extensive margin (permanent or temporary workforce) are more widespread than reductions in base or variable pay, the latter are usually combined with employment adjustments. This study also underlines the fact that adjustments to temporary employment are most commonly associated with adjustments to permanent employment.

These adjustments may of course have been made at different times, in line with a gradual deterioration in market conditions, as suggested by qualitative analyses (Perez et al., 2015; Roche \& Teage, 2014). These monographic studies describe sequential processes in which the most easily implementable and the most socially consensual adjustments are made first (such as the non-renewal of temporary contracts, the abolishing of overtime, recourse to vacation leave, and wage moderation or freezes). According to an approach that is more like an "improvised adaptation" (Roche \& Teage, 2014) than a trade-off strategy, the "toughest" adjustment (such as voluntary departures and collective redundancies) are only envisaged when the impact of the crisis worsens.

\section{Adjustments between constraints and opportunities}

Having identified typical adjustment combinations, the next step is to shed light on the reasoning behind these practices. The approach adopted consists in examining the diversity of practices in the light of the specific context of each firm, considering this context as a set of constraints and opportunities that influence managerial decisions (Amossé et al., 2008). Empirical studies exploring the response of firms to the economic crisis -in various macro-institutional settings- point to a variety of explanatory factors, which suggest differences in terms of crisis exposure and adjustment margins, and clarify the structuring effects of size, sector and the skill level of the workforce. After reviewing these factors relating to the environment and internal organisation of the establishments, we will look at how they influence the adjustment practices implemented.

\section{The environment and internal organisation of the establishments}

The analysis involves four main categories of variables. Most of the corresponding indicators (based on the findings of the REPONSE survey) relate to 2010, that is the end of the period observed (see Online Complement C2). Therefore, they cannot be considered as having determined the adjustment practices identified. However, they do help us understand the key features of the organisational configurations in which these practices are promoted and 
developed, and, in so doing, help to clarify the reasoning behind them.

\section{Market conditions and economic health of the establishment}

The market conditions in which the establishment operates may influence the scale and type of adjustments made. The descriptive analysis showed that adjustments, no matter what their nature, are not specific to establishments directly affected by the crisis. However, the greater the decline in business, the more frequent these adjustments are. Not surprisingly, this is consistent with the general findings of the literature. Besides the magnitude of the shock, the predicted duration of its effects can also play a role. If the impact of the crisis is severe and the duration of its effects difficult to predict, employers may overreact by stepping up the adjustments they make (Greenhalgh et al., 1988). If the impact is believed to be temporary, businesses may decide to implement a workforce retention policy to retain specific employees (OECD, 2010, p. 42), or maintain wage levels to keep employees motivated (Askenazy et al., 2013).

In addition to the shock and the resulting uncertainty, more structural factors relating to the establishment's competitive environment and to its profit margins may influence adjustment decisions. Various studies highlight the impact of the degree of competitive pressure on the products market, which in theory affects the trade-off between selling price adjustments and cost adjustments (Babeckỳ et al., 2009; Bertola et al., 2012; Dias et al., 2013; Fabiani et al., 2015). According to these studies, firms that have limited market power - due primarily to the fact that they operate in international highly competitive markets - tend to make tougher adjustments to wage costs. A firm's adjustment margins also depend on its economic health. In France, Deroyon and Romans (2014) show that the propensity of establishments to reduce their workforce is higher if their profitability is below that of their competitors, and lower if their productivity is greater.

Therefore, besides the trend in activity from 2008 to 2010, various indicators are used to assess not only the volatility and scope of the market, but also the establishment's performance in terms of profitability, compared with its main competitors.

\section{Nature of labour relations}

The impact of the institutionalisation of labour relations is generally taken into consideration in wage bargaining models, where union presence and the centralisation of collective bargaining are assumed to constrain firms' choices regarding employment and wages (Cahuc, 1990). In view of this, several studies have explored the impact of these institutional constraints on firms' adjustment strategies, particularly in terms of wage rigidity and passing the adjustments not made on the wages onto employment (Babeckỳ et al., 2009; Bertola et al., 2012; Dias et al., 2013; Fabiani et al., 2015). However, the results of these studies are inconclusive. For example, Babeckỳ et al. (2009) show, based on European data, that wage bargaining at any level increases the probability that alternative means of adjusting wage costs will be used, rather than cutting base wages. This may suggest that trade union involvement in wage setting creates a rigidity that firms must work around to adjust their wage costs. However, the positive effect of union presence in terms of recourse to alternative strategies remains significant after introducing controls for wage rigidity in the regression. Therefore, this union effect cannot be reduced to a pressure on wages.

In fact, the institutionalisation of labour relations does not tip the balance of power in favour of employees, especially during an economic crisis when the social dialogue can be used by management for its own purposes (Béthoux et al., 2015; Delteil \& Dieuaide, 2012). This is especially true in France, where the Auroux laws made collective bargaining obligatory. Thus, based on the REPONSE survey, Deroyon and Romans (2014) and Amossé et al. (2016) show that wage and employment adjustments have frequently been associated with negotiations between management and labour.

Two indicators are used to assess labour relations in the establishment or its parent firm: Firstly, the presence of at least one trade union delegate and, secondly, the intensity of social dialogue, as measured by the number of formal and informal negotiations that took place from 2008-2010 (regardless of the issues addressed).

\section{Organisational flexibility tools and workforce characteristics}

An establishment's adjustment margins also depend on its organisational practices. The 
classification proposed by Atkinson and Meager (1986) distinguishes four types of flexibility in working arrangement and practices. The first type, "numerical flexibility", refers to a set of practices that enable firms to vary their volume of employment by adjusting their intensive or extensive margins through recourse to part-time employment, fixed-term contracts and working time flexibility. The second type, "functional flexibility", consists in developing worker versatility through training, so that the existing workforce can be assigned to different tasks depending on the needs of the business. The third type, "distancing", involves outsourcing the employment relationship through recourse to subcontracting, service providers or temporary work. The final type is "pay flexibility", which refers to reversible and incentive remuneration practices. Firms may combine the different flexibilities and segment their implementation across the workforce. Thus, in their "flexible firm" model, Atkinson and Meager distinguish a "core" group of workers, for which functional flexibility goes hand in hand with monetary incentives, apart from "peripheral" groups of workers upon which numerical flexibility and distancing strategies are based (Atkinson and Meager, 1986, p. 4-5).

The effect of these organisational practices on crisis adjustment mechanisms is not as clear in the literature as one might expect. To be more precise, while the effect of flexible pay components on the probability of wage adjustments in times of economic crisis has been clearly established (Babeckỳ et al., 2010; Bertola et al., 2012; Fabiani et al., 2015), that of flexible employment practices (by far the most widely studied) is much less clear-cut. In theory, firms should adjust their temporary workforce rather than their permanent workforce or wages (see, for example, Bertola et al. 2012). Because there is less employment protection for temporary workers, turnover in the temporary workforce is less costly for the firm. However, this does not seem to have been a significant factor during the economic crisis. Thus, Fabiani et al. (2015) show, based on European data, that while a high percentage of temporary workers encourages firms to cut temporary jobs, it does not reduce the probability that they will cut permanent jobs too. A similar finding was observed by Dias et al. (2013) in Portugal, Kwapil (2010) in Austria, Deroyon and Romans (2014) in France, and Zalgelmeyer et al. (2012) in Germany, all of whom argue that there is no significant link between the share of temporary workers in the payroll and the decision to reduce the overall workforce.

The REPONSE survey allows us to study the link between labour flexibility strategies and crisis adjustment practices, but the indicators it provides are imperfect. The data on recourse to these practices relate to 2010 alone, in other words the end of the period being studied. As there was a resurgence of the crisis in that year, we can nonetheless consider that it at least partially captures usual practices. The employment of external workers, which is proper to distancing strategies, is measured based on the number of temporary workers in relation to the establishment's workforce, and on the use of subcontractors for part of the establishment's core business. With regard to functional flexibility, the survey provides information on worker versatility, and on the level and objectives of training expenditure. It also contains data on wage flexibility. It provides information on the key criteria used by management to review wages (financial performance or branch recommendations), and on recourse to wage flexibility practices. Only those practices adopted at the management's discretion are considered (individual pay rises and bonuses). Recourse to numerical flexibility is reported in advance through the $D A D S$, which show the proportion of workers on fixed-term contracts in 2008 and the proportion of part-time workers in 2009, in relation to the total workforce.

\section{Economic and financial dependency relationships}

Empirical research into the economic crisis has shown the impact of parent-subsidiary links on the adjustment practices of establishments in France. Deroyon and Romans (2014) show that -all things being equal, and considering the trend in business volumes- establishments that belong to a group are more likely to be affected by workforce reductions. This also came out in the interviews conducted after the REPONSE survey, which revealed that some adjustments were made within the framework of relocation strategies implemented by groups in pursuit of profits (Perez et al., 2015). This effect is studied specifically by Cabannes et al. (2013), who show that subsidiaries, especially among groups with an international presence, have made greater adjustments both to their business volumes and their workforce, and this cannot be explained entirely by a greater fall in demand. According to the authors, this suggests 
the use of trade-off and repositioning strategies, inducing a reallocation of tasks within groups, which provides international firms with additional flexibility.

These findings are consistent with previous research showing that, during recessionary periods, gross job destruction is greater in firms belonging to a group than in independent firms (Boccara, 1998; Duhautois \& Lagarde, 2004; Picart, 2004). More generally, they echo previous studies that highlight the influence of interfirm relationships on employment management practices, in a context of blurred organisational boundaries (Grimshaw \& Rubery, 2005). As demonstrated by Perraudin et al. (2008b), the financial links established by governance structures, and the trade links inherent in supply chains, reshape the way power and control are exercised within and outside the firm, undermining the employer's autonomy and influencing labour management policy.

These economic and financial dependency relationships are assessed by means of several indicators. The governance structure of the firm to which the establishment belongs is determined by whether or not it is part of a group, its main shareholder category, and whether it is listed directly on the stock market or indirectly via the parent group or network. The contribution of subcontracting activities to the firm's turnover is used to determine whether or not it has subcontractor status. Lastly, the constraints that weigh on the establishment are also assessed by asking whether, in 2010, it was subject to "specific, quantified targets" in terms of "profitability", "wage costs" or "quality", and, if so, whether these were "priority targets".

\section{Characterisation of establishment types}

These variables enable us to establish the respective characteristics of the establishments associated with the three adjustment practices identified in the typology. The comparison of relative frequencies within the different classes of establishment reveals the most discriminant characteristics (see Online Complement $\mathrm{C} 1$, table C1-4). To identify those that -all things being equal- are significant, the descriptive analysis is completed by estimating a multinomial logit model (table 3). While it does not allow any conclusions regarding causal links, the model helps us to assess the characteristics that significantly affect the probability of an establishment belonging to one of the three adjustment classes, rather than to the two classes in which adjustments are typically not made (which are the baseline). Only these characteristics are discussed.

Of the establishments that belong to the class in which all adjustment practices are typically used (wage freezes or cuts, workforce reduction, short-time working and business reorganisation), over half operate in the manufacturing sector. Compared with all the other establishments, they have little control over their market conditions (international market, small market share, limited leeway for setting prices, future developments in their business difficult to predict). They are also struggling with significantly depressed demand: Almost a quarter of them report a strong decline in their business over the period in question ( $v s .7 \%$ overall). In addition, their profitability is less likely to be higher than that of their competitors. Labour relations, although characterised by a strong union presence and a relatively well-developed social dialogue, do not have a significant impact, all other characteristics being equal.

With regard to flexibility levers, these establishments are characterised by a low level of recourse to numerical flexibility, either through short-term contracts or part-time working. In fact, according to data from the $D A D S$, the fall in the number of short-term contracts explains relatively few of the workforce reductions in this class. Conversely, these establishments more frequently take steps to develop worker versatility $(57 \%$ of establishments in this class, $v s .45 \%$ overall). This enables them to reassign tasks according to the needs of their business. This functional flexibility may be regarded as a necessary condition for the frequent business reorganisations typical of this class, whether they involve bringing subcontracted work back in house $(27 \%$ vs. $8 \%$ overall) or refocusing on the establishment's core business (36\% vs. $13 \%$ overall). Worker versatility may also have facilitated the workforce reductions that accompany these internal adjustments, as the remaining workers can be assigned to new tasks. Conversely, recourse to external labour through temping agencies and subcontractors, which is a key feature of this predominantly industrial class, does not seem to have an effect per se. While these findings must be treated with caution, since they are based on data from 2010 , we can at least conclude that they do not make the combined adjustments typical of this class either more or less probable; in particular, the use of external labour does not prevent payroll 
reductions ${ }^{2}$. Lastly, the wage freezing and wage reduction policies typical of this class are associated with frequent recourse to wage flexibility practices. Nevertheless, the effect is significant only for non-executive staff.

Economic and financial dependency relationships also feature highly: Almost half of the establishments in this class belong to a firm that is part of a (most often unlisted) group, and $40 \%$ are subcontractors, whose subcontracting activities account for the majority of their turnover. They are more often than average majority-owned by foreign businesses or financial institutions, or by families, but the fact that they have foreign capital in their ownership structure is the only significant feature. The combined effect of subsidiarisation and majority foreign ownership may, as Cabannes et al. (2013) suggest, be the implementation of trade-off strategies across groups operating in several countries. The fact that the capital holders are far away may also make these firms less concerned about the social acceptability of their decisions (Pfeffer, 2007, p. 126).

Establishments belonging to the class in which restructuring with wage moderation are typically used (workforce reduction, business reorganisation, and wage moderation) are, compared with the sample as a whole, more likely to be large and well-established. They are characterised by a strong union presence and an active social dialogue. Their market conditions, although difficult, seem to be less strained than in the previous class. Considering the indicators selected, the only significant features are their limited leeway when it comes to price setting, and their declining business volumes over the period observed. They are also more likely to have smaller profit margins than their competitors.

In terms of flexibility levers, this type of establishment is similar to those in the previous class with, however, one interesting difference. In this class, where the typical response consists of wage moderation rather than wage cuts or freezes, recourse to a flexible wage system for

2. This finding may be connected with the structural use made of flexible forms of labour mobilisation, as suggested by the findings of Argouarch' \& Debauche (2010), who study the effects of temporary work on employment adjustment practices, based on French data. They show that in the event of a business shock, the temporary workforce absorbs the majority of the fluctuations in the first few months following the shock; then, gradually, the permanent workforce is adjusted too, so that, two years after the shock, the distribution of adjustments between the temporary workforce and the permanent workforce is similar to the respective proportion of each employment form prior to the shock. executives is the only over-represented and significant feature. In addition, these establishments are distinguished by their workforce (which is more likely to be skilled) and by their high training expenditure. Like the establishments in the previous class, they seem to be remarkably dependent, either economically or financially. A third of them are subcontractors, although they are less dependent on their subcontracting activities than the establishments in the previous class. Half of them belong to a group, which may or may not be listed on the stock exchange. However, in this case, the majority are listed. In fact, this class contains the highest proportion of establishments belonging to a listed group ( $19 \%$ vs. $13 \%$ overall). Besides wage cost targets, they are also frequently subjected to profitability indicators.

These findings partially reflect those of other studies that examine the impact of stock market listing on labour management methods. Conway et al. (2008) and Perraudin et al. (2008a) show, based on data from the 2004-2005 REPONSE survey, that stock market listing is associated both with a skilled labour force and high training expenditure, and with flexible wage systems and the outsourcing of work to temping agencies and subcontractors. This allows for greater flexibility in operating costs, and thus protects the bottom line. However, stock market listing does not seem to be associated with workforce retention policies in the event of a strong decline in business, as shown by Reynaud (2012) and Deroyon and Romans (2014).

The combined adjustments typical of this class can be seen as resulting from a defensive strategy in a strongly downward context. The aim is to protect profits by reducing both the workforce (which, according to the DADS, mainly affects permanent and skilled workers) and the scope of the business ( $49 \%$ have got rid of job functions and 38\% have shifted their focus back to their core business), while keeping the remaining workers motivated by implementing a wage moderation policy rather than freezing or cutting wages. The presence of trade unions, which is relatively strong in this class, seems to have facilitated rather than prevented these adjustments.

Establishments belonging to the class in which primarily wage-oriented adjustments are typically used (wage freezes or cuts and, to a lesser extent, short-time working and workforce reductions) have a less clear-cut profile than those in the previous two classes. All things 
Table 3

Characterisation of establishment types (multinomial logit model estimation)

\begin{tabular}{|c|c|c|c|c|c|c|}
\hline & $\begin{array}{r}\text { "All adj } \\
\text { practice } \\
\text { change } 0 \\
\text { in wor }\end{array}$ & $\begin{array}{l}\text { justment } \\
\text { s" vs. "no } \\
\text { r increase } \\
\text { rkforce" }\end{array}$ & $\begin{array}{r}\text { "Restructurir } \\
\text { moderatio } \\
\text { change o } \\
\text { in worl }\end{array}$ & $\begin{array}{l}\text { ing with wage } \\
\text { ion" vs. "no } \\
\text { or increase } \\
\text { rkforce" }\end{array}$ & $\begin{array}{l}\text { "Primari } \\
\text { oriented ac } \\
\text { vs. "no c } \\
\text { increase in }\end{array}$ & $\begin{array}{l}\text { ily wage- } \\
\text { djustments" } \\
\text { change or } \\
\text { n workforce" }\end{array}$ \\
\hline Constant & -5.30 & $* * *$ & -3.49 & $\star * *$ & -2.76 & $\star \star \star *$ \\
\hline Sector & & & & & & \\
\hline Manufacturing & 1.56 & *** & 0.20 & & 0.74 & *** \\
\hline Construction & -0.34 & & -0.10 & & -0.01 & \\
\hline Trade & ref & & ref & & ref & \\
\hline Transport & -0.08 & & 0.04 & & 0.12 & \\
\hline Education, health, social, culture & 0.81 & * & -0.47 & * & 0.34 & \\
\hline Other services & 0.63 & * & 0.05 & & 0.24 & \\
\hline Size of establishment & & & & & & \\
\hline Less than 20 employees & ref & & ref & & ref & \\
\hline 20 to 49 employees & -0.10 & & 0.26 & & -0.27 & \\
\hline 50 to 199 employees & -0.29 & & 0.05 & & -0.56 & ** \\
\hline 200 employees or more & 0.35 & & 0.41 & * & -0.37 & \\
\hline Age of establishment: 50 years or more & 0.26 & & 0.42 & $* * *$ & 0.14 & \\
\hline Market conditions and economic health & & & & & & \\
\hline Trend in activity from 2008-2010 & & & & & & \\
\hline No change & ref & & ref & & ref & \\
\hline Decline & 1.42 & $* * *$ & 1.09 & $* * *$ & 0.90 & *** \\
\hline Strong decline & 2.67 & $* * *$ & 1.51 & *** & 1.42 & *** \\
\hline Difficult to predict trend in activity & 0.69 & $* * *$ & 0.15 & & 0.59 & *** \\
\hline Market openness & 0.69 & $* * *$ & -0.08 & & 0.09 & \\
\hline Leeway to set prices & -0.34 & * & -0.23 & * & 0.25 & \\
\hline Profitability compared with competitors & & & & & & \\
\hline Lower & 0.14 & & 0.41 & $* * *$ & 0.33 & \\
\hline Equivalent & ref & & ref & & ref & \\
\hline Higher & -0.57 & ** & 0.01 & & 0.04 & \\
\hline Nature of labour relations & & & & & & \\
\hline Presence of union delegates in the establishment & 0.27 & & 0.46 & $* * *$ & 0.18 & \\
\hline Presence of collective bargaining & & & & & & \\
\hline Absent or weak & -0.31 & & -0.71 & $* * *$ & -0.46 & * \\
\hline Moderate & ref & & ref & & ref & \\
\hline Strong & 0.26 & & 0.10 & & -0.51 & *** \\
\hline Flexibility tools and workforce characteristics & & & & & & \\
\hline Over $10 \%$ of employees on part-time contracts (DADS 2009) & -0.45 & ** & 0.10 & & -0.22 & \\
\hline Over $8 \%$ of employees on fixed-term contracts (DADS 2008) & -0.44 & $\star *$ & 0.11 & & -0.02 & \\
\hline Worker versatility & 0.49 & $* \star *$ & 0.21 & * & -0.06 & \\
\hline Executive pay flexibility & 0.26 & & 0.30 & ** & -0.02 & \\
\hline Non-executive pay flexibility & 0.86 & *** & 0.13 & & 0.79 & $* * *$ \\
\hline Wage review criteria & & & & & & \\
\hline Financial performance & 0.92 & $* \star *$ & 0.50 & $* \star * *$ & 0.57 & *** \\
\hline Branch recommendations & -0.41 & $\star *$ & -0.45 & *** & -0.45 & ** \\
\hline Proportion of executives and intermediate professions (DADS 200 & & & & & & \\
\hline 0 to $15 \%$ & -0.24 & & 0.07 & & -0.09 & \\
\hline 15 to $50 \%$ & ref & & ref & & ref & \\
\hline Over $40 \%$ & -0.11 & & 0.46 & $* * *$ & -0.17 & \\
\hline Training expenditure & & & & & & \\
\hline Less than $1.5 \%$ & 0.11 & & 0.06 & & -0.29 & \\
\hline $1.5 \%$ to $3 \%$ & ref & & ref & & ref & \\
\hline More than $3 \%$ & 0.10 & & 0.25 & * & -0.31 & \\
\hline None & 0.17 & & -0.12 & & 0.02 & \\
\hline Economic and financial dependency relationships & & & & & & \\
\hline Inclusion in a group & & & & & & \\
\hline Listed group & 0.13 & & 0.61 & *** & 0.05 & \\
\hline Unlisted group & 0.38 & * & 0.45 & $* * *$ & 0.04 & \\
\hline Does not belong to a group & ref & & ref & & ref & \\
\hline Main shareholder category & & & & & & \\
\hline Foreign firms or organisations & 0.96 & ** & 0.47 & * & 0.71 & * \\
\hline French firms or organisations & 0.21 & & 0.11 & & 0.07 & \\
\hline Family & 0.56 & & 0.29 & & 0.50 & * \\
\hline Employees, state or other & 0.27 & & 0.00 & & 0.40 & \\
\hline No shareholders & ref & & ref & & ref & \\
\hline Subcontracting establishment & & & & & & \\
\hline Yes ( $+50 \%$ of business) & 0.44 & $* *$ & 0.00 & & -0.28 & \\
\hline Yes (-50\% of business) & -0.05 & & 0.55 & $* * *$ & 0.22 & \\
\hline No & ref & & ref & & ref & \\
\hline Priority target & & & & & & \\
\hline Profitability & 0.19 & & 0.28 & ** & -0.11 & \\
\hline wage costs & 0.72 & * & 0.62 & ** & -0.22 & \\
\hline Quality & -0.87 & $\star \star * *$ & -0.32 & * & -0.31 & \\
\hline Number of establishments in the class studied & 312 & & 496 & & 214 & \\
\hline Number of establishments in the reference class & 1350 & & 1350 & & 1350 & \\
\hline
\end{tabular}

Note: Results of the multinomial logit model estimation, where the probability of a firm belonging to an adjustment class is estimated in relation to its inclusion in the "workforce stability" or "workforce increase" classes (which are the baseline). With regard to flexibility tools, recourse to temporary workers and recourse to subcontractors are never significant, and have therefore been removed from the final specification presented here. Estimated coefficients are reported using *, ${ }^{* *}$ and ${ }^{* * *}$, corresponding to significance thresholds of $10 \%, 5 \%$ and $1 \%$ respectively.

Unless otherwise specified, the variables are taken from the 2010-2011 REPONSE survey, and relate to 2010.

Coverage: Establishments with 11 employees or more in the non-farm business sector, reporting no change or a decline in activity from 2008 to 2010 Sources: Dares REPONSE survey 2010-2011, "management representative" section, Sinapse, and DADS 2008-2009. 
being equal, few characteristics are significant. As in the first class, establishments are more likely to operate in the manufacturing sector, although in a lesser proportion ( $28 \% v s .59 \%)$. As in the second class, there is a size effect; however, it works in the opposite direction, since this class features the highest proportion of small establishments (54\% have less than 20 employees, compared with $43 \%$ overall). This may explain why the social dialogue in these establishments is only moderately active. While these establishments are comparably less exposed to competitive pressure, this does not seem to be a significant factor. Their market conditions are characterised above all by a decline in activity $(60 \%$ have seen some decline or a strong decline in their business volumes, compared with $41 \%$ overall) and by unpredictability ( $26 \%$ compared with $20 \%$ overall). The use of organisational flexibility tools is less widespread than in the previous classes. The only specific characteristics of this class are that wages are revised according to the firm's financial performance, and non-executive pay is flexible. It should be noted that, again, these practices are combined with wage reductions or freezes. The fact that these establishments have a limited range of flexibility levers due to their frequently small size (Bunel, 2008) may explain why they focus their actions on wages. These findings are similar to those obtained by Lai et al. (2016) based on British data (the WERS survey), which shows that, all things being equal, small and medium-sized firms are more likely to have been affected by the economic crisis than large firms, and to have responded with wage adjustments (in the form of wage freezes or cuts), rather than by reducing the workforce or the hours worked, or by changes in work organisation. According to these authors, SMEs have more latitude when it comes to setting wages due to more informal practices and less institutionalised labour relations; they may also be more compelled to make wage adjustments, which -because there is little leeway for workforce reductions and less opportunity to use other flexibility levers - could be seen as a matter of survival (Lai et al., 2016, p. 126). The descriptive analysis provides another element of interpretation: While, on the whole, these establishments had little recourse to negotiation over the period observed, they are the most likely to have conducted negotiations on working time. This suggests that these establishments may have adjusted hours worked beyond their recourse to the short-time working legal framework.
Lastly, compared to the establishments in the previous two classes, they seem to be less economically or financially dependent. In fact, they are more often family-owned, independent and seldom enter into subcontracting arrangements. It should be noted, however, that the presence of foreign capital increases the likelihood of an establishment belonging to this adjustment class (as was the case for the previous two classes).

\section{What underlying logic?}

The comparison of these three profiles of establishment allows us to assess the specific impact of their internal organisation and their environment on the adjustment practices adopted.

The effect of the economic context (market conditions and economic health of the establishments) is in line with expectations. The adjustments made by the establishments seem to be closely connected with the scale of the business shock and the resulting uncertainty. The over-representation of manufacturing in the first and third classes (all adjustment practices, and primarily wage-oriented adjustments) can be interpreted as the effect of expectations on the long-term nature of the crisis, as the manufacturing sector has structural difficulties that the economic crisis has only made worse. It could be argued, then, that these expectations are associated with adjustments such as wage freezes or cuts (common features of the two classes). Poor profitability and high competitive pressure are characteristic of classes with a high incidence of workforce reductions (classes one and two). Establishments with limited market power -due primarily to the fact that they operate in international markets- do see more extensive adjustments to wage costs.

The impact of the institutionalisation of labour relations confirms the findings of Deroyon and Romans (2014) and Amossé et al. (2016), based on the same survey. The presence of trade unions and an active social dialogue are either positively associated with adjustments, or do not have a significant effect. Trade union presence is more specifically characteristic of establishments that typically pursue the restructuring and wage moderation option, which suggests that, while such a presence may have had an impact on wages, that impact was modest: It is associated with wage moderation, but does not hinder wage freezes or cuts. 
Less expected was the influence of organisational flexibility on crisis adjustment practices, which goes against the predictions in the Atkinson and Meager model (1986) ${ }^{3}$. Firstly, recourse to external workers via temping agencies and subcontracting (a practice specific to "distancing strategies") is insignificant, all things being equal ${ }^{4}$. While the use of external workers may have limited the scale of adjustments borne by the core workforce, contrary to expectations it did not lessen the probability of workforce reductions. On the contrary, the descriptive analysis suggests that establishments that rely heavily on external workers are over-represented in classes one and two, which focused on workforce adjustments. However, this effect disappears when the establishment's environment is taken into consideration.

Furthermore, "numerical flexibility" (fixedterm contracts or part-time working) is negatively associated with an adjustment practice that combines all levers, but does not have a significant effect on the other two types of practice. The descriptive analysis shows that the two classes of establishment that typically make no or very few adjustments to their workforce - and are the baseline - make the most intensive use of these two flexible forms of employment. It also shows that, in the classes characterised by workforce adjustments, short-term contracts account only partially for workforce reductions. On the whole, therefore, the use of fixed-term contracts does not increase the probability of adjustments to the total workforce.

Lastly, recourse to wage flexibilization and functional flexibility is significant, but the effects are no more in line with the predictions in the flexible firm model. Wage flexibilization is associated with wage adjustments (restrictive wage policies), but the effect differs

3. It is worth repeating that these findings must be treated with caution, since data from the REPONSE survey regarding recourse to organisational adjustments relates only to the end of the period observed. It cannot be ruled out that such recourse may have increased or decreased in response to the economic crisis. This problem arises particularly in relation to numerical flexibility, since workers on fixed-term contracts are counted in the overall workforce, the variations in which we are trying to explain. The DADS alleviate the problem by providing information on the use of fixed-term contracts (in proportion to the total workforce) at the start of the period (2008), and on the use of part-time working midway through the period (2009). As for the other organisational adjustments, the indicator selected identifies the recourse by establishments during a resurgence of the crisis (marked by a rebound in temporary work). While the degree of recourse to these practices certainly varied as a result of the crisis, it may be assumed that their actual existence within the establishment is more stable.

4. The variables relating to the use of temporary workers and subcontractors are not significant. They have been removed from the final multinomial logit estimation and are therefore not shown in table 3. according to whether it applies to executive or non-executive staff. Wage flexibilization for non-executive staff is associated with establishments that typically implement wage freezes or cuts (classes one and three), whereas wage flexibilization for executive staff is more likely to take the form of wage moderation (class two). This distinction arises from the different uses made of these tools depending on the type of employees concerned. As shown by studies relating to previous editions of the REPONSE survey (Barreau \& Brochard, 2003; Brochard, 2008 ), the use of reversible and individual pay components is part of an incentive policy for executive staff. However, for non-executive staff, it is more likely to be driven by the desire for a more flexible wage bill. As expected, functional flexibility -which is reflected in worker versatility- seems to encourage the reorganisation of productive processes (classes one and two). However, it is also associated with workforce reductions, even if spending on training is high. For example, in class two, the skilled and permanent workforce has been a major contributing factor to job losses. Therefore, it may be assumed that versatility, by enabling the remaining workforce to be reassigned, acts as a lever for workforce reductions, more than it helps overall to maintain a stable workforce.

Economic and financial dependency relationships, which are connected with the establishment's governance structure or its status as a subcontractor, have a specific and clear-cut effect. Being majority owned by foreign investors, being a subsidiary of a (listed or unlisted) group, or being part of a subcontracting chain significantly affects the adjustments made by establishments. To be more precise, while the majority presence of foreign investors in the establishment's capital is a characteristic feature of all classes associated with adjustment practices (as opposed to classes having seen little or no adjustments), being part of a larger group is associated more specifically with practices such as workforce reductions (classes one and two). This confirms a finding that is well established in the literature. The impact of stock market listing is significant only in class two, where restructuring operations accompanied by wage moderation are typical. This may signal a commitment to maintaining financial incentives for a more frequently skilled workforce, whose remuneration is performance-based (Conway et al., 2008). As for the impact of being a subcontractor, which is a characteristic feature of classes 
one and two, the extent of the establishment's dependency on its subcontracting activities is a decisive factor: The most dependent establishments are also those that have made the most drastic adjustments (class one). Conversely, establishments that are the least dependent on external actors (parent company, stock market, principal) seem to be less affected by job losses and to favour primarily wageoriented adjustments.

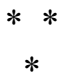

When viewed at establishment level, the responses to the economic crisis seem to be more heterogeneous than suggested by the analysis of aggregated data, both in terms of adjustment practices and underlying logic. Adjustments to the workforce, hours worked and wages are more complementary than substitutable, and are influenced not only by the economic and social context, but also by the labour flexibilization practices implemented within the establishment, and by its economic and financial dependency relationships. From an analytical perspective, two key lessons can be drawn from these findings.

Firstly, they challenge the theory that the effects of the crisis are split between a "core group" of protected workers, and "peripheral" groups of vulnerable workers who absorb most of the adjustments. They suggest -in line with critical studies of Atkinson et Meager's flexible firm model (1986) - a segmentation of human resource management practices within the "core" workforce (for a review of the literature, see Kalleberg, 2001).

Furthermore, these findings support the theory that organisational boundaries are "blurred" (Grimshaw \& Rubery, 2005), and that economic and financial dependency relationships deserve more consideration in the understanding of labour management practices. They provide further illustration of the constraints imposed by a governance structure or a subcontracting relationship that reduces the leeway of firms directed or controlled by external actors (Sacchetti \& Sugden, 2003; Perraudin et al., 2014).

\section{BIBLIOGRAPHY}

Amossé, T., Askenazy, P., Chevalier, M., Erhel, C., Petit, H. \& Rebérioux, A. (2016). Relations sociales et ajustements à la crise : une analyse micro-statistique comparative franco-britannique. CEE, Document de travail $\mathrm{N}^{\circ} 187$.

http://www.cee-recherche.fr/publications/documentde-travail/relations-sociales-et-ajustements-la-crise

Amossé, T., Bloch-London, C. \& Wolff, L. (2008). Les relations sociales en entreprise. Paris : La Découverte, coll. Recherche.

Argouarc'h, J. \& Debauche, E. (2010). Comment expliquer les évolutions de l'emploi depuis le début de la crise ? Insee, Note de conjoncture, Décembre, 19-43.

https://www.insee.fr/fr/statistiques/1408230? sommaire $=1408235$
Askenazy, P., Bozio, A. \& Garcia-Penalosa, C. (2013). Dynamique des salaires par temps de crise. Les notes du Conseil d'analyse économique 5. http://www.cae-eco.fr/Dynamique-des-salaires-pa r-temps-de-crise.html

Atkinson, J. \& Meager, N. (1986). Changing Working Patterns: How Companies Achieve Flexibility to Meet New Needs. IMS Report. Londres: National Economic Development Office.

Babeckỳ, J., Du Caju, P., Kosma, T., Lawless, M., Messina, J. \& Room, T. (2009). The margins of labour cost adjustment: survey evidence from European firms. ECB working paper series $\mathrm{N}^{\circ} 1106$. https://www.ecb.europa.eu/pub/pdf/scpwps/ ecbwp1106.pdf 
Barreau, J. \& Brochard, D. (2003). Les politiques de rémunération des entreprises : écarts entre pratiques et discours. Travail et Emploi, 93, 45-59. http://travail-emploi.gouv.fr/publications/Revue Travail-et-Emploi/pdf/93_1939.pdf

Beauvoir, R. \& Calavrezo, O. (2012). Le chômage partiel en 2011 : stabilisation du recours au dispositif. Dares Analyses $\mathrm{N}^{\circ} 097$.

http://dares.travail-emploi.gouv.fr/IMG/pdf/ 2014-097.pdf

Bentolila, S., Cahuc, P., Dolado, J. J. \& Le Barbanchon, T. (2012). Two-tier labor markets in a deep recession: France vs. Spain. Economic Journal, 122, 155-187.

Bertola, G., Dabusinskas, A., Hoeberichts, M., Izquierdo, M., Kwapil, C., Montornès, J. \& Radowski, D. (2012). Price, Wage and Employment Response to Shocks: Evidence from the WDN Survey. Labour Economics, 9, 783-791.

Béthoux, E., Mias, A., Blache, G., Dupuy, C., Jobert, A., Renoux, J. L., Spieser, C., Tallard, M. \& Vincent, C. (2015). Dialoguer plus, mais sur quoi ? Les régulations d'entreprise en matière d'emploi, de formation et de conditions de travail en temps de crise. La Revue de l'IRES, 84/1, 91-123. http://www.ires.fr/publications-de-l-ires/item/download /1180 8a9852ee87d8f638c282cad90a4a9f82

Boeri, T. \& Jimeno, J. F. (2016). Learning from the Great Divergence in unemployment in Europe during the crisis. Labour Economics, 41, 32-46.

Boulin, J. Y. \& Cette, G. (2013). Labour market adjustments during the crisis: the role of working time arrangements. Transfer, 19(4), 475-487.

Brochard, D. (2008). Logiques de gestion du travail, environnements conventionnel et concurrentiel : des politiques de rémunération sous influences. In: T. Amossé, C. Bloch-London \& L. Wolff, op. cit., 376-398.

Bunel, M. (2008). Flexibilité interne et flexibilité externe : complémentarité, substitution et impact des 35 heures. Document de travail du CEE $\mathrm{N}^{\circ} 98$. http://www.cee-recherche.fr/sites/default/files/ webfm/publications/docdetravail/98-flexibilite-complementarite-35heures.pdf

Cabannes, P.-Y., Cottet, V., Dubois, Y., Lelarge, C. \& Sicsic, M. (2013). Les ajustements des entreprises françaises pendant la crise de 2008/2009. L'économie française, édition 2013, 53-67. https://www.insee.fr/fr/statistiques/1372834? sommaire $=1372840$
Cahuc, P. (1990). La théorie des négociations salariales : une revue de la littérature. Économie et Prévision, 92(1), 21-30.

www.persee.fr/doc/ecop_0249-4744_1990_num_ 92_1_5154

Calavrezo, O. \& Zilloniz, S. (2016). L'ajustement des entreprises pendant la crise de 2008 : recours aux heures supplémentaires et à l'activité partielle. Dares, Document d'études N 198.

http://dares.travail-emploi.gouv.fr/IMG/pdf/ de_2016-198_-_4.pdf

Cochard, M., Cornilleau, G. \& Heyer, E. (2010). Les marchés du travail dans la crise. Economie et Statistique, 438-440, 181-204.

https://www.insee.fr/fr/statistiques/fichier/1377163/ ES438L.pdf

Conway, N., Deakin, S., Konzelmann, S., Petit, H., Rebérioux A. \& Wilkinson, F. (2008). The Influence of Stock Market Listing on Human Resource Management: Evidence for France and Britain. British Journal of Industrial Relations, 46(4), 631-673.

Delpech, Q., Garner, H., Guézennec, C. \& Naboulet, A. (2016). Collective Bargaining and Internal Flexibility: A Franco-German Comparison. France Stratégie, Document de travail, 2016-2. http://www.strategie.gouv.fr/sites/strategie.gouv. $\mathrm{fr} /$ files/atoms/files/collective_bargaining_and internal_flexibilty-26-02-2016.pdf

Delteil, V. \& Dieuaide, P. (2012). French multinational companies, new state regulations and changes in the employment relationship during the crisis: the exemplary case of the automobile sector. Transfer: European Review of Labour and Research, 18(4), 427-444.

Deroyon, J. \& Romans, F. (2014). La négociation sur l'emploi et les salaires face à la crise : des situations sous tension. Insee, Emploi et salaires, édition 2014, 61-78.

https://www.insee.fr/fr/statistiques/1373549? sommaire $=1373556$

Dias, D. A., Robalo Marques, C. \& Martins, F. (2013). Wage Rigidity and Employment Adjustment at the Firm Level: Evidence from Survey data. Labour Economics, 23, 40-49.

Duhautois, R. \& Lagarde, P. (2004). Entreprises de groupe ou entreprises indépendantes : quel impact sur les réallocations d'emplois ? Economie et Statistique, 380, 63-81.

https://www.insee.fr/fr/statistiques/1376496? sommaire $=1376498$ 
Dustmann, C., Fitzenberger, B., Schönberg, U. \& Spitz-Oener, A. (2014). From Sick Man of Europe to Economic Superstar: Germany's Resurgent Economy. Journal of Economic Perspectives, 28(1), 167-188.

Fabiani, S., Lamo, A., Messina, J. \& Room, T. (2015). European firm adjustment during times of economic crisis. ECB working paper series $\mathrm{N}^{\circ} 1778$. https://www.ecb.europa.eu/pub/pdf/scpwps/ ecbwp1778.en.pdf

Gautié, J. (2011). France: Protecting the insiders in the crisis and forgetting the outsiders? In: Vaughan-Whitehead D. (Ed), Inequalities in the world of work: The effects of the crisis, 209-254. Geneva: International Labour Office.

Greenhalgh, L., Lawrence, A. T. \& Sutton, R. I. (1988). Determinants of Work Force Reduction Strategies in Declining Organizations. Academy of Management Review, 13(2), 241-254.

Grimshaw, D. \& Rubery, J. (2005). Inter-capital relations and the network organisation: redefining the work and employment nexus. Cambridge Journal of Economics, 29, 1027-1051.

Horny, G., Montornes, J., Sauner-Leroy, J.-B. \& Tarrieu, S. (2010). Les politiques salariales durant la crise : résultats d'enquêtes. Bulletin de la Banque de France $\mathrm{N}^{\circ} 179,1-10$.

www.acp.banque-france.fr/fileadmin/user_upload/ .../bdf_bm_179_etu_1.pdf

Kalleberg, A. L. (2001). Organizing flexibility: The flexible firm in a new century. British Journal of Industrial Relations, 39(4), 479-504.

Kümmerling, A. \& Lehndorff, S. (2014). The use of working time-related crisis response measures during the Great Recession. ILO, Conditions of Work and Employment series $\mathrm{N}^{\circ} 44$.

Kwapil, C. (2010). Firms' Reactions to the Crisis and their Consequences for the Labour Market: Results of a Company Survey Conducted in Austria. ECB working paper series $\mathrm{N}^{\circ} 1274$.

https://www.ecb.europa.eu/pub/pdf/scpwps/ ecbwp1274.pdf

Lai, Y., Saridakis, G., Blackburn, R. \& Johnstone, S. (2016). Are the HR Responses of Small Firms Different from Large Firms in Times of Recession? Journal of Business Venturing, 31, 113-131.
Marchand, O. \& Minni, C. (2010). Le marché du travail dans la crise : un cadrage statistique. Revue de l'OFCE, 115(4), 63-80.

OCDE (2010). Perspectives de l'emploi de l'OCDE 2010. Paris : Ocde.

Perez, C., Thévenot, N., Berta, N., Brochard, D., Delahaie, N., Jallais, S., Perraudin, C., Sauviat, C. \& Valentin, J. (2015). Modes d'ajustement par le travail en temps de crise : des relations professionnelles sous tension. La Revue de l'Ires, 1/2015, $\mathrm{N}^{\circ} 84,59-90$.

https://halshs.archives-ouvertes.fr/hal-01306493/ document

Perraudin, C., Petit, H. \& Rebérioux, A. (2008a). The Stock Market and Human Resource Management: Evidence from a Survey of French Establishments, Recherches économiques de Louvain, 74(4), 541-581.

Perraudin, C., Petit, H., Thèvenot, N., Rebérioux, A. \& Valentin, J. (2008b). Une gestion de l'emploi qui dépasse le cadre de l'entreprise. In: T. Amossé, C. Bloch-London \& L. Wolff, op. cit., 277-297.

Perraudin, C., Petit, H., Thèvenot, N., Tinel, B. \& Valentin, J. (2014). Inter-firm Dependency and Employment Inequalities: Theoretical Hypotheses and Empirical Tests in French Subcontracting Relationships. Review of Radical Political Economics, 46(2), 199-220.

Pfeffer, J. (2007). Human Resources from an Organizational Behavior Perspective: Some Paradoxes Explained. Journal of Economic Perspectives, 21(4), 115-34.

Picart, C. (2004). Le tissu productif : renouvellement à la base et stabilité au sommet. Economie et statistique, 371, 89-108.

https://www.insee.fr/fr/statistiques/1376315?som maire $=1376317$

Reynaud, B. (2012). Workforce reduction and firm performance: evidence from French firm data (1994-2000). Socio-Economic Review, 11(4), $711-737$

Roche, W. K. \& Teague, P. (2014). Do Recessions Transform Work and Employment? Evidence from Ireland. British Journal of Industrial Relations, 52(2), 261-285.

Sacchetti, S. \& Sugden, R. (2003). The governance of networks and economic power: The nature and impact of subcontracting relationships. Journal of Economic Surveys, 17(5), 669-691. 
Teague, P. \& Roche, W. K. (2014). Recessionary bundles: HR practices in the Irish economic crisis. Human Resource Management Journal, 24(2), 176-192.

Tijdens, K., van Klaveren, M., Bispinck, R., Dribbusch, H. \& Öz, F. (2014). Wage and workforce adjustments in the economic crisis in Ger- many and the Netherlands. European Journal of Industrial Relations, 20(2), 165-183.

Zagelmeyer, S., Heckman, M. \& Kettner, A. (2012). Management Responses to the Global Financial Crisis in Germany: Adjustment Mechanisms at Establishment Level. The International Journal of Human Resource Management, 23(6), 3355-3374. 